\title{
EFEKTIVITAS PENAMBAHAN SERUM SAPI PESISIR FASE BERAHI TERHADAP PEMATANGAN OOSIT KERBAU SECARA IN VITRO
}

\author{
J. HENDRI ${ }^{1}$, HARISSATRIA ${ }^{1}$, A. ASRI ${ }^{1}$ DAN JASWANDI ${ }^{2}$ \\ ${ }^{1}$ Universitas Mahaputra Muhammad Yamin \\ ${ }^{2}$ Fakultas Peternakan Universitas Andalas \\ Jl. Jenderal Sudriman No.6, Kp. Jawa, Tj. Harapan, Solok, Sumatera Barat, 27317 \\ E-mail:jonhendri@ymail.com
}

\begin{abstract}
This study aims to determine the percentage of buffalo oocytes matured in TCM-199 medium supplemented bovine serum pesisir estrus phase in vitro. Furthermore, to improve the efficiency of in vitro embryo production in buffalo cattle with bovine serum pesisir supplementation estrus phase.Buffalo oocytes matured in TCM-199 medium in 5\% $\mathrm{CO}_{2}$ incubator and each treatment was added bovine serum pesisir estrus phase with different concentrations $10 \%, 10 \%$ and 20\%).Parameters observed in this study is the percentage of buffalo oocytes matured without the addition of bovine serum pesisir estrus phase, the percentage of mature oocytes by the addition of bovine serum pesisir estrus phase $10 \%$ and the percentage of buffalo oocytes were matured by the addition of bovine serum pesisir estrus phase $20 \%$ are in vitro.Percentage of buffalo oocytes matured with the addition of bovine serum pesisir phase estrus as much $20 \%$ showed a highly significant difference $(P<0.01)$ which is $70.04 \%$ when compared with the maturation by the addition of $10 \%$ bovine serum pesisir is $56.00 \%$ and without bovine serum pesisir estrus phase is $36.96 \%$ are in Virto.Based on the results of this study concluded that supplementation with bovine serum pesisir phase concentration of $20 \%$ in the maturation medium TCM-199 significantly $(P<0.01)$ in increasing the level of maturation of buffalo oocytes in vitro compared with the addition of bovine serum pesisir estrus phase and without the addition of $10 \%$ bovine serum pesisir (control).
\end{abstract}

Keywords : in vitro, serum, bovine pesisir, estrus phase

\section{PENDAHULUAN}

Ditinjau secara fisiologis, kerbau merupakan hewan semi akuatik (sedikit kelenjer keringat) dan tidak tahan dengan kondisi suhu panas. Akibat dari keadaan tersebut mengakibatkan efisiensi reproduksi yang rendah seperti silent heat, calving interval yang panjang sehingga mengakibatkan angka kelahiran yang rendah. Selanjutnya ternak kerbau memiliki jumlah folikel dalam ovarium yang sedikit, rendahnya respon superovulasi (Haldar dan Prakash, 2007).

Salah satu upaya yang dapat dilakukan untuk meningkatkan efisiensi reproduksi ternak kerbau adalah dengan teknologi fertilisasi in vitro. Dengan teknologi fertilisasi in vitro, ovarium kerbau yang terbuang dari hasil pemotongan di Rumah Potong Hewan (RPH) dapat dimanfaatkan sebagai sumber embrio (Kochar et al., 2002). Teknologi fertilisasi in vitro juga memberikan kesempatan untuk menghasilkan embrio yang layak untuk di transfer, namun peningkatan yang berarti belum terlihat pada pelaksanaan fertilisasi in vitro pada ternak kerbau, karena dipengaruhi oleh faktor media dan komposisi media yang digunakan belum sempurna selama proses pematangan dan kultur secara In Vitro (Nandi et al., 2002).

Secara teknis, rangkaian kegiatan fertilisasi in vitro terdiri atas serangkaian kegiatan yang meliputi pematangan oosit, fertilisasi, dan kultur embrio yang menggunakan beberapa bahan-bahan kimia yang dijual oleh industri farmasi dan diformulasi sebagai media untuk hidupnya embrio. Penggunaan bahan-bahan kimia tersebut belum sempurna untuk mempertahankan viabilitas oosit sampai perkembangan tahap embrio. Selain bahan kimia, serum juga banyak mengandung protein, vitamin, mineral serta hormon estradiol yang dapat menghasilkan faktor pertumbuhan sehingga penambahan serum ke dalam media pematangan oosit dapat dijadikan sebagai bahan alternatif sebagai sumber nutrisi dan membantu pertumbuhan oosit sampai tahap embrio secara in vitro (Ganong, 2003).

Serum atau plasma darah adalah bagian dari darah, merupakan suatu larutan yang luar biasa mengandung banyak sekali ion, molekul anorganik dan molekul organik yang diangkut ke berbagai bagian tubuh atau membantu transport zat-zat lain. serum mengandung gas, glukosa, lemak, subtansi non protein, nitrogen, enzim, hormon, vitamin, dan pigmen. Protein 
serum terdiri dari $90 \%$ air dan $10 \%$ zat padat. Bahan padat ini terdiri dari $7 \%$ protein yang meliputi antibodi, phospolipida kolesterol, glukosa, enzim sedangkan bahan anorganik bukan protein terdiri dari $\mathrm{P}, \mathrm{Na}, \mathrm{Ca}, \mathrm{K}, \mathrm{Mg}, \mathrm{Fe}$, dan $\mathrm{HCO}_{3}$ (Ganong, 2003).

Serum mengandung bermacam-macam protein dan mineral yang merupakan sumber unsur hara makro dan mikro. Kandungan protein atau mineral di dalam serum darah dari berbagai hewan berlainan baik kualitas dan kuantitasnya, karena hal ini di pengaruhi oleh macam pakan hewannya. Kandungan unsur hara yang dimiliki dalam komponen serum darah sapi antara lain $(\mathrm{mg} / 100 \mathrm{gr})$ yaitu $\mathrm{N}=$ 0,0084; $\mathrm{P}=0,1000 ; \mathrm{K}=0,0098 ; \mathrm{C}$-Organik = 3,2760; Bahan Organik $=56,4800$; Kadar Air = 93,9590 dan komponen serum darah ayam antara lain yaitu $\mathrm{N}=0,0058 ; \mathrm{P}=0,2000 ; \mathrm{K}=$ 0,0145; C-Organik $=5,3040 ;$ Bahan Organik $=$ 9,1400, dan Kadar Air $=89,930 \%$ (Dukes dalam Rahayu, 2002).

Konsentrasi hormon estrogen dan estradiol dalam serum sapi tergantung pada fase berahi pada hewan tersebut. Konsentrasi hormon estradiol dalam serum pada fase puncak berahi pada seekor hewan yaitu 211,25-247,77 pg/ml (Widiyono et al., 2011). Meidan et al., (1993) menyatakan konsentrasi estradiol sapi pada folikel dominan 379,6 $\mathrm{ng} / \mathrm{ml}$. Jyotsna dan Medhamurti (2009) menyatakan konsentrasi estradiol kerbau pada folikel dominan 125,8 $\mathrm{ng} / \mathrm{ml}$. Selanjutnya menurut hasil penelitian Harissatria (2010), konsentrasi estradiol dalam media pematangan oosit kerbau setelah ditambahkan sel folikel de graaf sapi yaitu $3053,3 \mathrm{pg} / \mathrm{ml}$.

Peningkatan yang berarti dalam pelaksanaan teknologi fertilisasi in vitro ternak kerbau belum terlihat begitu signifikan karena mahalnya biaya produksi embrio, belum sempurnanya pematangan oosit serta fertilisasi in vitro yang rendah. Pada penelitian ini dicoba penambahan beberapa konsentrasi serum sapi pesisir fase berahi kedalam media pematangan oosit kerbau sebagai bahan alternatif untuk meningkatkan angka pematangan oosit kerbau secara in vitro. Penambahan beberapa konsentasi serum sapi pesisir fase berahi diharapkan dapat meningkatkan angka pematangan oosit kerbau secara in vitro dan meningkatkan efisiensi produksi embrio kerbau secara in vitro.

\section{MATERI DAN METODE}

Materi dalam penelitian ini menggunakan ovarium ternak kerbau yang telah terbuang dari Rumah Potong Hewan kemudian diambil dan dimasukkan dalam termos yang berisi $\mathrm{NaCl}$ fisiologis $0,9 \%$ dan dibawa ke laboratorium untuk dilakukan koleksi oosit.

Oosit dari ovarium ternak kerbau yang di potong di Rumah Potong Hewan (RPH) dibawa ke laboratorium dengan termos yang berisi $\mathrm{NaCl}$ fisiologis $0,9 \%$ pada temperatur $30-35^{\circ} \mathrm{C}$. Koleksi oosit dari ovarium dilakukan dengan cara menyayat ovarium (slicing) dengan ukuran folikel 2-6 mm dalam Petri dish yang berisi media PBS yang ditambahkan dengan beberapa konsentrasi serum sapi pesisir fase berahi $10 \%$ dan $20 \%$ serta Gentamisin 10 $\mu \mathrm{g} / \mathrm{ml}$. Oosit yang terlepas dari ovarium langsung diamati di bawah mikroskop, dan oosit yang digunakan dalam pematangan adalah oosit yang dikelilingi oleh sel-sel kumulus kompak dan mempunyai sitoplasma yang homogen.

Prosedur pematangan dilakukan menurut prosedur yang dikemukakan Boediono et al., (2003). Oosit yang diperoleh dicuci 2 kali dalam media PBS dan dilanjutkan dalam media pematangan. Media pematangan oosit yang digunakan adalah TCM-199. Media TCM-199 ditambahkan dengan serum sapi pesisir fase berahi $10 \%$ dan $20 \%$ serta Gentamisin $10 \mu \mathrm{g} / \mathrm{ml}$ sebagai antibiotik.

Setelah oosit kerbau terkoleksi, maka selanjutnya dilakukan pembagian jumlah oosit yang didapat secara sama banyak dan dimasukkan ke dalam masing-masing yaitu penambahan serum sapi pesisir fase berahi $0 \%$ sebagai kontrol, $10 \%$ sebagai perlakuan pertama dan $20 \%$ sebagai perlakuan ke dua dan dilapisi dengan mineral oil dan ketiga Petridis tersebut dimasukkan dalam inkubator $\mathrm{CO}_{2} 5 \%$ selama 24 jam.

Oosit yang telah mengalami proses pematangan dalam media TCM-199 yang ditambahkan serum sapi pesisir fase berahi selama 24 jam pada incubator $\mathrm{CO}_{2} 5 \%$, dicuci untuk membuang sel-sel kumulusnya dalam media TCM-199. Setelah pencucian oosit selesai, oosit langsung diamati untuk melihat ekspansi sel komulus atau polar bodi yang dihitung berdasarkan persentase oosit matang 
dibagi dengan jumlah yang dimatangkan dikali 100\% (Kobayashi et al., 1994).

\section{Peubah yang Diamati}

1. Persentase oosit kerbau yang matang tanpa penambahan serum sapi pesisir fase berahi dalam media pematangan secara in vitro.

2. Persentase oosit kerbau yang matang dengan penambahan serum sapi pesisir fase berahi $10 \%$ dalam media pematangan secara in vitro.
3. Persentase oosit kerbau yang matang tanpa penambahan serum sapi pesisir fase berahi $20 \%$ dalam media pematangan secara in vitro.

Rancangan yang digunakan dalam penelitian ini adalah Rancangan Acak Kelompok (RAK) dengan 3 perlakuan dan 6 ulangan sebagai kelompok (hari). Data yang diperoleh dianalisis secara statistik dengan menggunakan sidik ragam (Analysis of Variance/ANOVA), seperti pada Tabel 1.

Tabel 1. Analisis keragaman rancangan acak kelompok (RAK)

\begin{tabular}{|c|c|c|c|c|c|c|}
\hline \multirow{2}{*}{ SK } & \multirow{2}{*}{ DB } & \multirow{2}{*}{ JK } & \multirow{2}{*}{ KT } & \multirow{2}{*}{$F_{\text {hitung }}$} & \multicolumn{2}{|c|}{$\mathrm{F}_{\text {tabel }}$} \\
\hline & & & & & 0,05 & 0,01 \\
\hline Perlakuan & $(3-1)=2$ & JKP & $\mathrm{JKP} / 2$ & KTP/KTS & 3,33 & $\overline{5,64}$ \\
\hline Kelompok & $(6-1)=5$ & JKK & $\mathrm{JKK} / 5$ & KTK/KTS & 4,10 & 7,56 \\
\hline Sisa & $(\mathrm{t}-1)(\mathrm{k}-1)=10$ & JKS & $\mathrm{JKS} / 5$ & & & \\
\hline Total & $($ t.r-1) $=17$ & JKT & & & & \\
\hline Keterangan & $\begin{array}{l}\text { SK }=\text { Sun } \\
\text { F.Hitung < F.Ta } \\
\text { F.Hitung > F.Ta } \\
\text { F.Hitung > F.Ta }\end{array}$ & $\begin{array}{l}\text { ggaman } \\
\text { berbeda } \\
\text { berbeda } \\
\text { berbeda }\end{array}$ & $\begin{array}{l}\text { k nyata) } \\
\text { ta) } \\
\text { gat nyata) }\end{array}$ & & & \\
\hline
\end{tabular}

Jika hasil $\mathrm{F}$ Hitung berbeda nyata dan sangat nyata, maka analisis dilanjutkan dengan uji DMRT (Duncan's Multiple Range Test) (Steel dan Torrie, 1994).

\section{HASIL DAN PEMBAHASAN}

\section{Persentase Oosit Kerbau yang Matang pada Masing-masing Penambahan Serum Sapi Pesisir Fase Berahi $(0 \%, 10 \%$, dan $20 \%)$ Secara In Vitro}

Berdasarkan hasil penelitian dan analisis statistik, maka persentase oosit yang matang pada masing-masing perlakuan dalam media TCM-199 dengan penambahan serum sapi pesisir fase berahi adalah, kontrol $(36,96 \%)$, perlakuan penambahan serum sapi pesisir $10 \%$ $(56,00 \%)$, dan perlakuan $20 \% \quad(70,04 \%)$. Persentase tingkat kematangan pada masingmasing perlakuan dapat dilihat pada Tabel 2.

Tabel 2. Persentase oosit kerbau yang matang pada berbagai penambahan serum sapi pesisir fase berahi $(\%)$

\begin{tabular}{lcc}
\hline \multicolumn{1}{c}{ Perlakuan } & $\mathrm{n}$ & Persentase Oosit Kerbau Matang (\%) \\
\hline A (kontrol) & 58 & $36,96^{\mathrm{a}}$ \\
B (penambahan serum 10\%) & 59 & $56,00^{\mathrm{a}}$ \\
C (penambahan serum 20\%) & 60 & $70,04^{\mathrm{b}}$ \\
\hline
\end{tabular}

Keterangan : Superskrip yang berbeda pada kolom yang sama menunjukkan berbeda sangat nyata $(\mathrm{P}<0,01)$

Hasil analisis statistik menunjukkan bahwa penambahan serum sapi pesisir fase berahi sebanyak $20 \%$ dalam media pematangan oosit kerbau secara in vitro menghasilkan persentase kematangan sangat nyata $(\mathrm{P}<0,01)$ lebih tinggi dibandingkan pematangan dengan penambahan serum sapi pesisir fase berahi $10 \%$ dan tanpa penambahan serum sapi pesisir fase berahi. Persentase kematangan oosit kerbau dengan penambahan serum sapi pesisir fase berahi dengan konsentrasi $10 \%$ dan tanpa penambahan serum sapi pesisir fase berahi tidak menunjukkan perbedaan yang nyata $(\mathrm{P}>0,05)$.

Hal ini berarti bahwa penambahan serum sapi pesisir fase berahi dengan konsentrasi $20 \%$ dalam media pematangan oosit kerbau cukup efektif untuk meningkatkan keberhasilan pematangan oosit kerbau secara in vitro. Persentase kematangan yang lebih tinggi dari penambahan serum sapi pesisir fase berahi dengan konsentrasi $20 \%$ diduga serum 
sapi pesisir fase berahi lebih banyak menghasilkan hormon estradiol yang berguna dalam proses pematangan inti dan sitoplasma oosit. Penambahan serum sapi pesisir $10 \%$ dan tanpa penambahan serum sapi pesisir fase berahi tidak signifikan karena sedikitnya hormon estradiol yang disekresikan dalam media pematangan sehingga tidak begitu menunjang pematangan dari oosit kerbau secara in vitro.

Tingginya persentase tingkat kematangan oosit kerbau dengan penambahan serum sapi pesisir dengan konsentrasi $20 \%$ karena serum sapi pesisir fase berahi lebih dominan mensekresi estradiol, sehingga dapat merangsang pertumbuhan oosit untuk tahap selanjutnya. Hasil penelitian tersebut sependapat dengan yang dinyatakan oleh Skiner dalam Trounson (1992), bahwa pengaruh positif dari adanya serum sapi fase berahi pada proses maturasi oosit in vitro diduga bereaksi melalui sel-sel kumulus atau secara langsung pada oosit. Serum juga mengandung faktor pertumbuhan yang memiliki peranan dalam pengaturan maturasi oosit, khususnya melalui sel-sel kumulus. Selanjutnya menurut Adlak et al., (2008) penambahan $1 \mu \mathrm{l} / \mathrm{ml}$ estradiol akan meningkatkan pematangan oosit kerbau secara in vitro.

Peningkatan konsentrasi serum dalam media pematangan dengan batasan tertentu akan meningkatkan rataan maturasi tahap MII. Hal ini berarti semakin meningkat konsentrasi serum diduga akanmeningkatkan konsentrasi berbagai komponen pemicu terjadinya proses maturasi yang terkandung di dalam serum seperti hormon, protein, energi dan berbagai faktor lainnya sehingga memberikan hasil yang optimal pada proses maturasi oosit. Hasil penelitian ini diperkuat oleh penelitian sebelumnya menurut Djati et al. (1999), bahwa tingkat maturasi oosit kambing tahap M-II dalamTCM-199+20\% EGS (estrus goat serum) $(68,0 \%)$ lebih baik dibandingkan dengan TCM1-99+10\% EGS $(50,0 \%)$. Rao et al. (2002), mengatakan bahwa suplementasi ESS20\% dalam media maturasi TCM-199 menghasilkan tingkat maturasi tahap M-II oosit domba sebesar 86,0\%. Dapat disimpulkan bahwa konsentrasi serum $20 \%$ dalam media maturasi memberikan pengaruh yang positif terhadap peningkatan angka maturasi. Pendapat ini juga diperkuat oleh pernyataan Lonergan (1992) dan Monaghan yang disitasi Gordon (1994) bahwa konsentrasi serum terbaik untuk maturasi oosit in vitro bervariasi antara10-20\%.

Penggunaan serum hewan estrus pada hari ke 7 pasca estrus memberikan hasil yang lebih baik dibandingkan serum jenis lain. Hendri (1999) mendapatkan angka pematangan yang lebih tinggi pada media yang menggunakan serum induk estrus (H0) dan awal estrus (H7) dibandingkan dengan FBS 5\%. Hasil penelitian tersebut dikemukakan bahwa penggunaan kedua serum disarankan 10-15\%. Jenis serum lain yang sering ditambahkan dalam medium adalah Calf Serum (CS) dan Bovine Serum Albumin (BSA) (Gordon, 1994)

Dalam serangkaian proses pelaksanaan pematangan oosit secara in vitro, banyak hal dan faktor yang mempengaruhi diantaranya, pemilihan media yang tepat dan faktor-faktor pertumbuhan yang terkandung dalam media. Media pematangan oosit mempunyai peranan penting terhadap kelanjutan proses fertilisasi in vitro. Media pematangan oosit yang digunakan dalam pematangan tidak hanya berpengaruh terhadap jumlah oosit yang dapat mencapai tahap M-II, dan mampu untuk melaksanakan fertilisasi, tetapi juga berpengaruh terhadap perkembangan embrio selanjutnya (Bavister et al., 1992; Totey et al., 1993). Penambahan FSH $10 \mu \mathrm{l} / \mathrm{ml}$ dalam media pematangan dapat meningkatkan kematangan oosit, sehingga oosit mampu melakukan fertilisasi atau perkembangan embrio berikutnya (Brackett et al., 1989; Saeki et al., 1990).

Penelitian pematangan oosit domba secara in vitro penambahan serum domba juga berpengaruh terhadap angka maturasi oosit. Suplementasi serum domba estrus (ESS) hari ke-0 konsentrasi $10 \%$ dan serum pasca estrus (hari ke-6) konsentrasi $10 \%$ dalam media TCM-199 menghasilkan tingkat maturasi oosit domba tahap metafase-II $(68,7$ dan $67,6 \%)$, lebih baik dibandingkan dengan fetal lambserum (FLS) konsentrasi 10\% (32,9\%) (Rusiyantono et al., 2000).

Super-ovulated cow serum (SCS) konsentrasi $10 \%$ dan fetal calf serum (FCS) konsentrasi $10 \%$ dalam media TCM199 menghasilkan tingkat maturasi oosit domba tahap metafase-II (28,0 dan 22,2\%) (Djuwita et al., 1995). ESS konsentrasi $20 \%$ dan ovine 
follicular fluid (OFF) konsentrasi 20\% dalam media TCM199 menghasilkan tingkat maturasi oosit domba tahap metafase-II masing-masing ESS $(86,0 \%)$ dan OFF $(76,0 \%)$ (Rao et al., 2002).

Selama ini serum yang digunakan sebagai bahan suplementasi berasal dari industri farmasi seperti: estrus cow serum (ECS), bovine serum (BS), fetal calf serum(FCS), bovine serum albumin (BSA) dan serum domba(SS) dengan harga relatif mahal, kemasan besar danpada daerah tertentu sulit didapat. Mengingat factor tersebut maka perlu diupayakan serum alternatif seperti : ESS yang dapat diadakan di laboratorium dan digunakan sebagai bahan suplementasi untuk meningkatkan kualitas media. Penelitian bertujuan meneliti pengaruh SS dan ESS dengan berbagai konsentrasi terhadap tingkat maturasi dan fertilisasi oosit domba in vitro.

Penelitian ini menggunakan media TCM199 (Sigma), dan suhu dalam inkubator CO2 berkisar $38^{\circ} \mathrm{C}$, kualitas dari oosit yang digunakan adalah kualitas A dengan tandatanda oosit dikelilingi oleh sel kumulus yang kompak, sitoplasma yang homogen dan umur dari oosit tersebut setelah diambil sampai selesai dikoleksi tidak lebih dari 6 jam. Sumber serum sapi pesisir yang digunakan adalah serum sapi pesisir pada fase berahi. Oosit kerbau yang digunakan pada penelitian ini menggunakan oosit dari ukuran besar dari 5 $\mathrm{mm}$ dan dapat dilihat pada gambar di bawah ini.

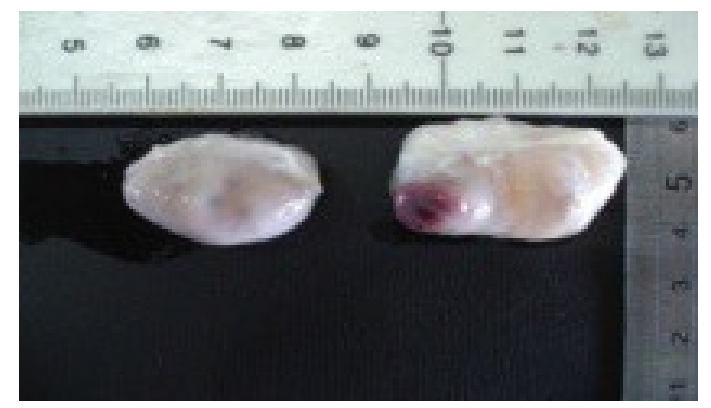

Gambar 1. Ovarium dan ukuran folikel kerbau

Keadaan morfologis oosit yang mengalami pematangan yang sempurna dapat dilihat dari adanya perkembangan inti oosit, adanya satu polar bodi. Disamping itu, apabila diamati dari keadaan sel kumulusnya terlihat adanya ekspansi atau penyebaran sel-sel kumulus disekeliling oosit setelah dimatangkan
(Kobayashi et al., 1994). Kondisi oosit matang dengan sel kumulus yang memperlihatkan ekspansi dan polar bodi dapat dilihat pada Gambar 2 dan 3.

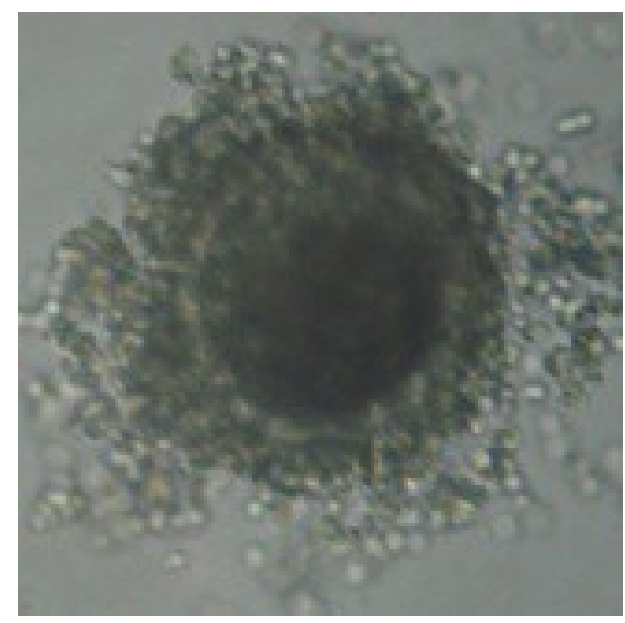

Gambar 2. Oosit yang matang dengan ekspansi sel komulus

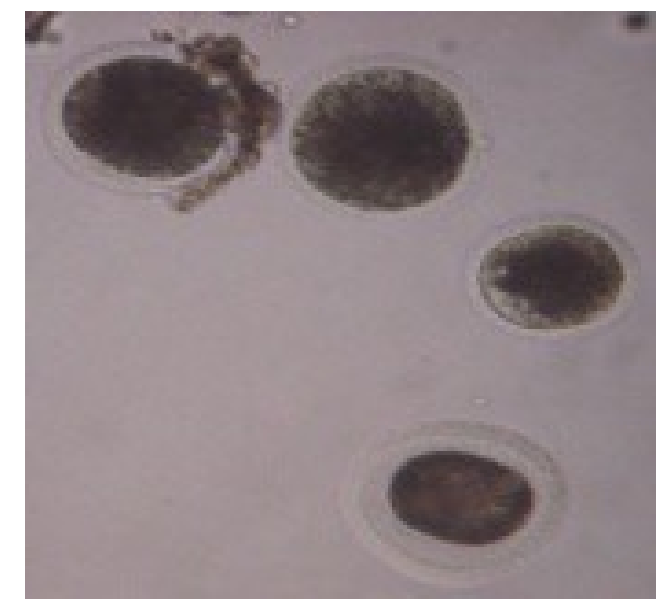

Gambar 3. Oosit yang matang dengan penampakan 1 polar body

\section{KESIMPULAN}

Berdasarkan hasil penelitian dapat disimpulkan bahwa serum sapi pesisir fase berahi dengan konsentrasi $20 \%$ dalam media maturasi TCM-199 sangat nyata $(\mathrm{P}<0,01)$ meningkatkan tingkat maturasi oosit kerbau secara invitro dibandingkan dengan penambahan serum sapi pesisir fase berahi $10 \%$ dan tanpa penambahan serum sapi pesisir (kontrol).

Dengan hasil penelitian tersebut, serum sapi pesisir fase berahi dapat digunakan sebagai serum alternatif untuk meningkatkan persentase angka pematangan pada oosit kerbau secara in vitro. 


\section{DAFTAR PUSTAKA}

Adlak, S.A., K.P. Khillare, K.P, Pawshe, C.H and Mude. 2008. Influence of Serum and Hormones on In vitro maturation of Buffalo Oocytes. Veterinary World. 1(8) : 243-244.

Bavister, B.D., T.A. Rose-Hallekant and T. Pinyopummintr. 1992. Development of in vitro matured/in vitro fertilized bovine embryos in to morulae and blastocysts in defined culture media. Theriogenology 37 : 127-146.

Boediono A, T. Suzuki, and R. Godke. 2003. Comparison of hybrid and purebred in vitroderived cattle embryos during in vitro culture. Anim Reprod Sci. 78 : 1-11.

Brackett, B.G., A.I. Younis and R.A. FayrerHosken. 1989. Enhanced viability after in vitro fertilization of bovine oocytes matured in vitro with high concentration of luteinizing hormone. Fertil. Steril. 52 : 319-324.

Djati, S., Fatchiyah, G. Ciptadi, N. Ianaini, S. Wahyuningsih, S. Rahayu dan L. Anggraini. 1999. Tingkat transformasi inti oosit kambing pada medium TCM-199 dengan berbagai konsentrasi estrus goat serum. Abstrak Seminar Penelitian Aktual Bioteknologi Reproduksi di Indonesia. Forum Komunikasi Reproduksi, Malang, 19-20 Mei 1999.

Djuwita, I., B. Purwantara, M. Fahrudin and Y. Sukra. 1995. The effect of superovulated cow serum on in vitro maturation and fertilization in sheep. Pros. Symposiumon Biotechnology of Animal Reproduction, Bogor. hlm.20-22.

Ganong W.F. 2003. Buku Ajar Fisiologi Kedokteran.Widjajakusumah HMD Penerjemah; Jakarta: Penerbit Buku Kedokteran EGC. Terjemahan dari: Review of Medical Physiology

Gordon, I. 1994. Laboratory Production of Cattle Embryos. Biotechnology in Agri-cultural Series. CAB. Int.

Haldar, A. and B.S. Prakash. 2007. Effect of exogenous growth-hormone-releasing factor on blood metabolites and minerals in late maturing buffalo heifers (Bubalusbubalis). J. Anim. Physiol. Anim. Nutr. 91:326-332.

Harissatria. 2010. Persentase kematangan dan fertilisasi oosit kerbau dengan penambahan sel folikel kerbau dan sapi secara In Vitro. Thesis
Program Pascasarjana Universitas Andalas. Padang.

Hendri. 1999. Penambahan berbagai jenis serum pada medium TCM-199 untuk produksi embrio sapi melalui teknik fertilisasi in vitro. Jurnal peternakan dan Lingkungan. 5 : 1-8.

Jyotsna U.R. and R. Medhamurthy. 2009. Standardization and validation of an induced ovulation model system in buffalo cows: characterization of gene expression changes in the periovulatory follicle. Animal Reproduction Science. 113(1-4) : 71-81.

Kobayashi, K., S. Yamashita, and H. Hoshi 1994. Influence of epidermal growth factors and transforming growth factors on in vitro maturation of cumulus cell enclosed bovine oocytes in a defined medium. J. Reprod. Fertil. $100:$ 439-446.

Kochar, H.P., B. Wu, L.H. Morris, B.C. Buckrell, J.W. Pollard, P.K. Basrul and W.A. King. 2002. Maturation status, protein synthesis and development competence of oocytes derived from lambs and ewes. Reprod. Domes. Anim. $37: 19-25$.

Lonergan. P, Syarif H, Monaghan P, Wahid H, Gallagher M and Gordon I. 1992. Effec of Size on Bovine Oocyte Morphology and Embrios Yield Following Maturation, Fertilization and Cultur In Vitro. Theriogenology 54 : 1420-1429.

Meidan, R., D. Wolfenson, W.W. Thatcher, E. Gilad, L. Aflalo, Y. Greber, E. Shoshani and E. Girsh. 1993. Oxytocin and estradiol concentrations in follicular fluid as a means for the classification of large bovine follicles. Theriogenology. 39 : 421-432.

Nandi, S., H.M. Raghu, B.M. Ravindranatha, and M.S. Chauhan. 2002. Production of buffalo (Bubalus bubalis) embryos in vitro: premises and promises. Reprod. Domest. Anim. 37 : $65-74$.

Rao, B.S., K.S. Naidu, D. Amarnoth, R. Vagdevi, A.S. Rao, K.V. Brahmhandv. and H. Rao. 2002. In vitro maturation of sheep oocytes in different media during breeding and nonbreeding seasons. Small Rumin. Res. 43 : 3136.

Rusiyantono,Y., I.Djuwita, B. Purwantara and Y. Sukra. 2000. The influence of ewe serum on in vitro oocyte maturation and early development of ovine embryos. Media Vet. $7(1)$ : 13-16. 
Saeki, K., M.L. Leibfried-Rutledge and N.L. First. 1990. Are fetal calf serum and hormones necessary during in vitro maturation of cattle oocytes for subsequent development. Theriogenology. 33:316 (Abst).

Steel, R.G.D. and J.H. Torrie. 1994. Prinsip dan Prosedur Statistik. Suatu Pendekatan Biometrik (diterjemahkan oleh: B. Soemantri). Gramedia, Jakarta.
Widiyono. I., Prabowo P. P, Sarmin , Pudji. A, Claude M. A. 2011. Kadar Estradiol dan Progesteron Serum, Tampilan Vulva dan Sitologi Apus Vagina Kambing Bligon Selama Siklus Birahi. Jurnal Veteriner. 12(4) : 263-268.

Totey, S.M., C.H. Pawshe and G.P. Singh. 1993. In vitro maturation and fertilization of buffalo oocytes : effect of media hormone and sera. Theriogenology 39 : 1153-1171. 